\title{
RENDAM KAKI AIR HANGAT JAHE DALAM MENURUNKAN TEKANAN DARAH PADA PASIEN HIPERTENSI
}

\author{
Nurpratiwi ${ }^{1}$, Uti Rusdian Hidayat ${ }^{2}$, Sri Bintang Putri ${ }^{3}$,
}

\author{
1.2.3 STIKes Yarsi Pontianak
}

\author{
Nurpratiwi : Program Studi Pendidikan Ners, STIKes YARSI Pontianak, Jl. Panglima A'im, \\ No.1 Pontianak Timur, Kota Pontianak, Kalimantan Barat-78232, \\ *Email:nurpratiwi466@gmail.com
}

\begin{abstract}
Abstrak
Latar Belakang: Hipertensi merupakan penyakit kompleks yang menurunkan kualitas hidup pasien dengan akibat terjadinya komplikasi. Penangganan dapat diberikan rendam kaki air hangat jahe. Kandungan jahe yaitu minyak atsiri dapat memperlebar pembuluh darah yang nantinya berefek menurunkan tekanan darah. Sudah banyak yang menggunakan rendam kaki untuk menurunkan tekanan darah di Wilayah Puskesmas Tanjung Hulu Pontianak Timur. Tujuan: Untuk mengetahui bagaimana pengalaman rendam kaki air hangat jahe dalam menurunkan tekanan darah pada pasien hipertensi di Wilayah Puskesmas Tanjung Hulu Pontianak Timur. Metode: Metode kualitatif dengan pendekatan fenomenologi. Jumlah partisipan 5 orang yang diambil dengan teknik snowball sampling pengumpulan data diperoleh melalui teknik wawancara terstruktur. Hasil: Pengalaman partisipan yaitu perasaan yang dirasakan oleh partisipan memberikan rasa enak dan nyaman, manfaat dapat menurunkan tekanan darah dan mengurangi nyeri, waktu melakukan pada pagi hari dan waktu yang dilakukan sekitar 10-20 menit, prosedur dalam melakukan rendam kaki air hangat jahe dengan jahe diiris-iris/ditumbuk/digeprek, jenis jahe yang sering digunakan yaitu jahe putih dan jahe kuning, tidak ada efek samping yang muncul setelah melakukan rendam kaki air hangat jahe. Kesimpulan: Didapatkan 6 tema yaitu perasaan setelah melakukan rendam kaki air hangat jahe, manfaat rendam kaki air hangat jahe dalam menurunkan tekanan darah, waktu melakukan rendam kaki air hangat jahe, prosedur dalam melakukan rendam kaki air hangat jahe, jenis jahe yang digunakan, efek samping yang muncul setelah melakukan rendam kaki air hangat jahe. Rekomendasi : Diharapkan bagi penderita hipertensi dapat memanfaatkan terapi rendam kaki air hangat jahe sebagai terapi alternatif dalam menurunkan tekanan darah.
\end{abstract}

Kata kunci: Rendam Kaki Air Hangat Jahe, Hipertensi.

Daftar pustaka: 43 (2010-2019)

\begin{abstract}
Background: Hypertension is a complex disease that decreases the quality of life of patients with complications. Handling can be given by soaking the feet of warm ginger water. The content of ginger which is essential oil can widen blood vessels which later has the effect of lowering blood pressure. Many people have used foot baths to reduce blood pressure in the Tanjung Hulu Health Center in East Pontianak. Purpose: To find out how the experience of soaking the ginger foot warm water in lowering blood pressure in hypertensive patients in the Tanjung Hulu Health Center Area, East Pontianak. Method: Qualitative method with a phenomenological approach. Total of participants 5 people taken with snowball sampling technique data obtained through strucure interview techniques. Result: Participants experiences are the feelings felt by the participants giving a good and comfortable feeling, the benefits can reduce blood pressure and reduce pain, the time to do it in the morning and the time taken is about 10-20 minutes, the procedure in soaking the foot of warm water with ginger sliced gingersliced / pounded / crushed, the type of ginger that is often used is white ginger and yellow ginger, no side effects that appear after soaking the foot of warm water ginger. Conclusion: Six themes were obtained: feeling after soaking the feet of warm ginger water, the benefits of soaking the feet of warm water ginger in lowering blood pressure, when soaking the feet of warm water ginger, the procedure for soaking the feet of warm water ginger, the type of ginger used, side effects that appear after soaking the feet of warm water ginger. Recommendation : It is hoped that people with hypertension take advantage of ginger warm foot bath therapy as an alternative therapy in lowering blood pressure
\end{abstract}

Keywords: The Experience Soaking Feet with Ginger Warm Water, Hypertension. Source: 43 (2010-2019) 


\section{Pendahuluan}

Penelitian ini dilatarbelakangi berdasarkan penggalaman pribadi peneliti sebagai mahasiswa perawat pada waktu melakukan pengkajian asuhan keperawatan pada pasien hipertensi saat dinas dirumah sakit, peneliti melihat bahwa pasien yang menderita hipertensi lebih suka melakukan pengobatan non farmakologi seperti menggunakan pengobatan tradisional seperti herbal-herbal walaupun sudah diberikan obat dari resep dokter, karena pasien menganggap bahwa jika mengkonsumsi obat-obatan kimia semakin membuat efek samping yang lebih besar dibandingkan dengan pengobatan tradisional.

Fenomena lain yang peneliti temukan, ada keluarga yang juga mengalami penyakit hipertensi berumur sudah tua bahwa dia mengatakan walaupun sudah didiagnosis oleh dokter bahwa dia menderita penyakit hipertensi tetapi sangat jarang mengkonsumsi obat-obatan yang diberikan dari resep dokter. Beliau beranggapan bahwa pengobatan tradisional lebih mendapatkan efek yang lebih menyegarkan ditubuhnya dibandingkan obat yang diresepkan dari dokter, beliau juga mengatakan sering mengkonsumsi minuman jahe serta menggunakan rendam kaki air hangat dengan menggunakan jahe.

Berdasarkan studi pendahuluan yang dilakukan di wilayah Puskesmas Tanjung Hulu Pontianak Timur yang dilakukan dirumah pasien yang menderita hipertensi pada bulan Mei 2020 peneliti melakukan teknik wawancara langsung kepada pasien tersebut terkait pengobatan apa saja yang dilakukan untuk mengurangi tekanan darah yang diderita pasien selama dirumahnya. Peneliti menemukan 3 diantaranya mengatakan sering mengkonsumsi obat dari resep dokter, dan juga memakan buahbuahan yang dapat menurunkan tekanan darah, dan ada juga yang mengatakan biasa melakukan pengobatan tradisional juga dirumahnya seperti meminum air jahe dan melakukan rendam kaki air hangat jahe untuk menurunkan tekanan darah.

Berdasarkan penelitian terdapat efektivitas terapi rendam kaki air jahe hangat terhadap penurunan tekanan darah pada lansia dengan hipertensi (Hartati, 2016).

Menurut Rottie dkk (2017) yang berjudul "Pengaruh terapi rendam kaki dengan air hangat terhadap penurunan tekanan darah pada pasien dengan hipertensi di Puskesmas Bahu Manado" hasil penelitian berdasarkan uji friedman didapatkan bahwa $\mathrm{p}$ - value $=0,689>(\mathrm{a}=$ $0,05)$, maka tidak terdapat perbedaan antara hasil tekanan darah sistolik setelah terapi rendam kaki dengan air hangat o2, o3, o4. Berdasarkan uji wilcoxon, terdapat pengaruh sebelum dan sesudah dilakukan terapi rendam kaki dengan air hangat terhadap penurunan tekanan darah ( $\mathrm{p}$-value $=0,000)$. Kesimpulan dari penelitian ini, terapi rendam kaki dengan air hangat tidak efektif menurunkan tekanan darah pada pasien dengan hipertensi di puskesmas bahu manado.

Berdasarkan penelitian Hartati (2016) dan Sucipto \& Setiyono (2018) di dapatkan hasil adanya hubungan rendam kaki air jahe hangat terhadap penurunan tekanan darah pada penderita hipertensi. Sementara pada penelitian Rottie dkk (2017), tidak adanya hubungan rendam kaki dengan penurunan tekanan darah pada penderita hipertensi. Perbedaan tersebut dapat terjadi karena banyak faktor. Perlu adanya penelitian lebih lanjut untuk mengetahui faktor-faktor yang mempengaruhinya. Pengalaman yang dialami oleh pasien hipertensi yang menggunakan rendam kaki air hangat jahe masih perlu diperdalam, penangganan ini harus terus dipelajari sehingga nantinya mempunyai landasan yang kuat. Apalagi hipertensi merupakan penyakit degeneratif yang dapat dialami oleh semua orang.

Studi fenomenologi tentang pengalaman pasien hipertensi terhadap perawatan dirinya yang diteliti oleh Elvi dkk (2018), di dapatkan 8 tema besar yaitu respon terhadap penyakit, pengalaman pertama melakukan kontrol, mengatasi dengan obat, menjaga kesehatan tubuh, perubahan pola makan, tidak merokok dan minum alkohol serta dukungan keluarga. Pada tema menjalani pengobatan beberapa partisipan klien teratur menjalani 
pengobatan karena berbagai alasan yang dikemukakan. Dimungkinkannya karena takutnya efek samping dari obat sehingga mereka banyak menggunakan teknik pengobatan tradisional.

Menurut Wahyuningsih (2013), hipertensi atau dikenal dengan darah tinggi merupakan gangguan pada pembuluh darah yang mengakibatkan suplai oksigen dan nutrisi yang dibawa oleh darah terhambat sampai ke jaringan tubuh yang membutuhkan. Hipertensi suatu keadaan dimana tekanan darah sistolik atau diastoliknya melebihi 140/90 $\mathrm{mmHg}$. Hipertensi yang terjadi secara terus menerus merupakan salah satu faktor penyebab berbagai penyakit yang berhubungan dengan kardiovaskuler seperti stroke, gagal jantung, serangan jantung, dan kerusakan ginjal (Sutanto, 2010).

Berdasarkan data World Health Organization (2015), hipertensi merupakan masalah besar, tidak hanya di Negara barat tapi juga di Indonesia. Hipertensi diderita oleh 1,13 miliar orang di seluruh dunia artinya 1 dari 3 orang di dunia terdiagnosis hipertensi, dan diperkirakan tahun 2025 akan naik menjadi 1,5 miliar orang. Setiap tahun hipertensi atau tekanan darah tinggi menyumbang kematian hampir 9,4 juta orang akibat penyakit jantung dan stroke dan jika di gabungkan, kedua penyakit ini merupakan penyebab kematian nomor satu di dunia.

Hipertensi di Indonesia merupakan masalah kesehatan yang tinggi dengan prevalensi yaitu tahun 2013 tercatat dengan jumlah $25,8 \%$, terjadi peningkatan ditahun 2018 dengan jumlah 34,1 \%. Jumlah tertinggi berada di provinsi Kalimantan Selatan $(44,1 \%)$ dan terendah ada di provinsi Papua (22,2\%), Kalimantan Barat sendiri berada pada urutan ke lima dengan prevalensi hipertensi yaitu sebesar 36,99\% (Kemenkes RI, 2018).

Menurut penelitian Marliana (2017), hipertensi dapat menimbulkan kerusakan organ tubuh, baik secara langsung maupun tidak langsung. Kerusakan organ-organ yang umum ditemui pada pasien hipertensi adalah penyakit jantung, penyakit menyerang otak, penyakit ginjal, penyakit arteri perifer, dan retinopati.

$$
\text { Data Dinas Kesehatan Kota }
$$

Pontianak (2019), pada tahun 2018 berjumlah 31.737 kasus dan meningkat pada tahun 2019 menjadi 47.125 kasus. Berdasarkan data capain penderita hipertensi Kota Pontianak tahun 2019 tercatat bahwa di Puskesmas Tanjung Hulu berada di peringkat kedua di Pontianak Timur menunjukan jumlah kasus hipertensi sebanyak 5.390 kasus dan capaian penderita hipertensi yang datang kelayanan kesehatan sebanyak 1664 (30,9\%). Hipertensi termasuk dalam kategori 3 terbesar pada bulan Februari dari 10 penyakit terbesar di Puskesmas Tanjung Hulu pada tahun 2020, yang berarti menunjukan bahwa sebagian besar masyarakat diwilayah Tanjung Hulu menderita hipertensi. Dari data di atas penulis tertarik melakukan penelitian kualitatif tentang Pengalaman Rendam Kaki Air Hangat Jahe Dalam Menurunkan Tekanan Darah Pada Pasien Hipertensi Di Wilayah Puskesmas Tanjung Hulu Pontianak Timur.

\section{Metode}

Penelitian menggunakan metode kualitatif. Pendekatan kualitatif yang digunakan adalah fenomenologi. Fenomenologi adalah suatu pendekatan dalam mempelajari makna dari pengalaman manusia menjalani suatu fase dalam kehidupannya, tujuan dari penelitian fenomenologi adalah memahami makna dari pengalaman kehidupan yang dialami oleh partisipan dan menjelaskan perspektif filosofi yang mendasari fenomena tersebut (Dharma, 2017).

Penelitian ini bertujuan untuk mengetahui bagaimana "Pengalaman Rendam Kaki Air Hangat Jahe Dalam Menurunkan Tekanan Darah Pada Pasien Hipertensi Di Wilayah Puskesmas Tanjung Hulu Pontianak Timur".

Pada penelitian ini sampling yang dipergunakan adalah dengan teknik snowball sampling digunakan untuk memperbanyak jumlah subjek apabila diperlukan informasi yang lebih mendalam. 


\section{Hasil}

\section{Karakteristik Partisipan}

Tabel 4.1

Karakteristik partisipan pengalaman

rendam kaki air hangat jahe dalam

menurunkan tekanan darah pada pasien

hipertensi Diwilayah Puskesmas

Tanjung Hulu Pontianak Timur

\begin{tabular}{cccc}
\hline Koding & Jenis Kelamin & Usia & Agama \\
\hline P1 & Laki-laki & 50 & Islam \\
\hline P2 & Perempuan & 74 & Islam \\
\hline P3 & Perempuan & 46 & Kristen \\
\hline P4 & Perempuan & 48 & Islam \\
\hline P5 & Perempuan & 54 & Islam \\
\hline \multicolumn{4}{c}{} \\
\hline Suku & $\begin{array}{c}\text { Pendidika } \\
\text { n }\end{array}$ & $\begin{array}{c}\text { Pekerjaa } \\
\text { n }\end{array}$ & TD \\
\hline Bugis & SD & Swasta & $150 / 9$ \\
& \multicolumn{2}{c}{0} \\
\hline Bugis & Tidak & IRT & $160 / 9$ \\
& Sekolah & & 2 \\
\hline Dayak & SMP & IRT & $153 / 8$ \\
& \multicolumn{2}{c}{7} \\
\hline Jawa & SD & IRT & $165 / 9$ \\
& & \multicolumn{2}{c}{4} \\
\hline Melay & Tidak & IRT & $155 / 8$ \\
u & Sekolah & & 3 \\
\hline
\end{tabular}

Sumber: Data primer

Kriteria usia untuk partisipan penelitian yang telah ditetapkan sebelumnya yaitu mulai dari usia $\geq 18$ tahun. Semua partisipan seperti yang terlihat pada tabel 4.1 telah sesuai dengan kriteria tersebut dengan usia termuda yaitu 46 tahun dan usia paling tua yaitu 74 tahun. Jenis kelamin yaitu sebanyak 4 partisipan berjenis kelamin perempuan dan 1 partisipan berjenis kelamin laki-laki. Jenis agama yang dianut oleh partisipan adalah beragama Islam dan Kristen. Jenis suku partisipan terdiri dari suku Bugis, Dayak, Jawa dan Melayu. Adapun tingkat pendidikan partisipan dengan tingkat pendidikan yaitu Sekolah Menengah Pertama (SMP) dan pendidikan terendah yaitu Sekolah Dasar (SD) serta juga ada yang tidak bersekolah. Menyeimbangkan Proporsi dan memaksimalkan variasi dari data demografi partisipan penelitian merupakan hal yang perlu diperhatikan oleh peneliti, mengingat prinsip dalam menilai kecukupan data penelitian kualitatif adalah ketika data yang dikumpulkan dari penelitian sudah saturasi dan variasi sudah maksimal.

\section{Analisis Tematik}

Tema-tema dikelompokkan kedalam enam kategori yang meliputi: perasaan setelah melakukan rendam kaki air hangat jahe, manfaat rendam kaki air hangat jahe dalam menurunkan tekanan darah, waktu melakukan rendam kaki air hangat jahe, prosedur dalam melakukan rendam kaki air hangat jahe, jenis jahe yang digunakan, efek samping yang muncul setelah melakukan rendam kaki air hangat jahe. Adapun sub tema dari tema-tema tersebut adalah:

1. Perasaan setelah melakukan rendam kaki air hangat jahe

Perasaan yang dirasakan oleh partisipan seperti yang telah diungkapkan partisipan berikut ini:

"Enak itu, enak rase badan tu tengkok tu..." (P.1)

"Agak nyamanlah gitu, badannye kakinye bepeloh rasenye.."(P.2)

"Saya rasa tu panas, rase naek ke badan jadi enak, enaklah gitu ye"(P.3)

"Lumayanlah, direndam pakai air jahe tu rase rase nyerinya tu berkurang"(P.4)

"Ya agak lumayan sih...kebetulan badan saya kurang sehat ni....bawaan badan ni kurang sehat badan ni... tapi kaki saye alhamdulillah enak...rasenye panas"(P.5)

Hasil percakapan diatas dapat dilihat partisipan banyak merasakan enak dan nyaman setelah melakukan rendam kaki air hangat jahe.

2. Manfaat rendam kaki air hangat jahe dalam menurunkan tekanan darah

Manfaat yang diungkapkan partisipan adalah sebagai berikut:

“...Untuk ngilangkan darah tinggi...terutama untuk ngurangi tekanan darah lah tu.."(P.1)

"Merasekan badan ni sehat ni kan segarlah..darah tinggi..."(P.2)

"Menghangatkan badan, menyegarkan badan, buang keringat"(P.3)

“..Rase nyerinya tu berkurang ...kaki pun ringan...endak sakit gitu dibawak jalan..."(P.4) 
“...Asam urat, urat saraf tejepit tu kan...tapi kaki alhamdulillah enak"(P.5)

Hasil percakapan diatas dapat disimpulkan bahwa partisipan merasakan manfaat rendam kaki air hangat jahe untuk menurunkan tekanan darah dan mengurangi nyeri.

3. Waktu melakukan rendam kaki air hangat jahe

Waktu yang dilakukan partisipan dalam melakukan rendam kaki air hangat jahe di ungkapkan partisipan adalah sebagai berikut:

“..20 menit 15 menit sampai aeknye tu ... hah tu pagi tu bagos"(P.1)

" Tadik pagi jam 6 lewat...karne waktu pagi hari kan bagos...selama 15 menit kalau airnye sejuk"(P.2)

“..Pagi hari ..setengah 8 lah gituk..15 menitlah"(P.3)

"15 menit.. pagi jam-jam 7 an..dipagi hari kan”(P.4)

"Sekitar 10 menit lah...kalau pagikan tu ye kadang lupa..kadang pas tidurlah malam tu..itu kan enak tidurnye bangon pagi pagi tu enak"(P.5)

Hasil percakapan diatas dapat disimpulkan bahwa waktu partisipan melakukan rendam kaki air hangat jahe pagi hari lama waktu melakukan sekitar 10-20 menit.

4. Prosedur dalam melakukan rendam kaki air hangat jahe

Prosedur yang dilakukan partisipan saat melakukan rendam kaki air hangat jahe diungkapkan partisipan sebagai berikut:

" Direndam aek hangat tu, masuk tempat yaa sangganlah...beri jahe ataupun ditumbuk ataupun diiris-iris masokkan kaki..ambek aek hangat kalok ditermos itu masokkan gituk camporkan jangan terlalu panas amat ye mane gak...dirase kalau kite katekan angatangat kuku tu kan..dengan kemampuan kitelah merasekan air hangat tu"(P.1) "Di ditumbok-tumbok. buat senggan ini benar-benar( diatas mata kaki)aku rendam ek.. liak tu ditumbok baru direndamkan barulah nyaman.."(P.2)

"Caranya siapkan baskom lalu panaskan air hangat, hangat-hangat kuku jak, lalu jahe dipotong-potong setelah itu direndam kaki sampai diatas mata kaki sampai airnye tu sejuk"(P.3) "Airnya dihangat, siapkan baskom baru masukkan dalam baskom, diiris-iriskan air anok jahe..hmm angat-angat kuku lah, baru kakinya direndam(sebatas mata kaki)"(P.4)

"Saya rebus digeprek direbus ke kaki sampai mata kaki.. rase-rase sendiri jak, hangat kuku kalau rase kurang panas tu tambah lah gitu"'(P.5)

Hasil dari percakapan diatas dapat disimpulkan bahwa prosedur partisipan dalam melakukan rendam kaki air hangat jahe dengan jahe diirisiris/ditumbuk/digeprek,direbus, masukk an ke wadah, kaki direndam sebatas mata kaki.

5. Jenis jahe yang digunakan

Berbagai jenis jahe yang digunakan oleh partisipan dapat dilihat dari setiap ungkapkan partisipan sebagai berikut:

"Jahe kuning...kalau merah ni biase juga..."(P.1)

"kalau jumpe kuning kuning, jumpe merah merah, kalau putih putih dipakai..yang bagosnye tu alaminye tu merah"(P.2)

"jahe putih"(P.3)

"jahe putih, pas adenye jahe putih kalau ade jahe merah jahe merahlah"(P.4)

"Endak tentu .. kalau ade pas ketemu jahe merah saye beli...habis jahe merahnye jahe putihlah dipakai" (P.5)

Hasil dari percakapan diatas dapat disimpulkan bahwa paling banyak digunakan partisipan yaitu jahe putih dan jahe kuning.

6. Efek samping yang muncul setelah melakukan rendam kaki air hangat jahe Efek samping yang muncul setelah melakukan rendam kaki air hangat jahe dapat dilihat dari setiap ungkapan partisipan sebagai berikut:

"Endak ade.. saye ngelakukan itu nyaman rase, kaki pon nyaman nak bejalan"(P.1)

"Endak,endak ade.. iye nyamanlah"(P.2) 
"Endak ade ..saya rasa tu panas.. rase naek kebadan badan jadi enak..enaklah gituk ye"(P.3)

"Endak ada..iya kaki pun ringan rasenye.. endak sakit gitu dibawak jalan"(P.4)

"Alhamdulillah endak ade pulak. iye endak ade, enak-enak jak..Alhamdulillah endak ade bagos jak"(P.5)

Hasil ungkapan setiap partisipan dapat disimpulkan bahwa semua partisipan mengatakan tidak ada efek samping yang muncul setelah melakukan rendam kaki air hangat jahe.

\section{Pembahasan}

\section{Interpretasi Hasil Penelitian}

1. Perasaan setelah melakukan rendam kaki air hangat jahe

Kategori pertama tentang perasaan setelah melakukan rendam kaki air hangat jahe. Sebagian besar partisipan mengatakan perasaan yang dirasakannya berupa enak dan nyaman setelah melakukan rendam kaki air hangat jahe.

Hasil penelitian ini partisipan mengungkapkan bahwa perasaan yang dirasakan oleh partisipan setelah melakukan rendam kaki air hangat jahe memberikan rasa enak dan nyaman pada partisipan tersebut. Efek saat merendam kaki air hangat jahe yang dapat memberikan rasa hangat, rasa hangat yang terjadi pada saat melakukan rendam kaki air hangat jahe yang akan beradaptasi terhadap pembuluh darah sehingga terjadi vasodilatasi yang dapat melancarkan peredaran darah.

Pada penelitian Prananda dkk(2017), Efek dari rendam kaki menggunakan air hangat menghasilkan energi kalor yang bersifat mendilatasi pembuluh darah dan melancarkan peredaran darah juga merangsang saraf yang ada pada kaki untuk mengaktifkan syaraf parasimpatis, sehingga menyebabkan perubahan tekanan darah. Efek biologis panas hangat dapat menyebabkan dilatasi pembuluh darah yang mengakibatkan peningkatan sirkulasi darah. Secara fisiologis respon tubuh terhadap panas yaitu menyebabkan pelebaran pembuluh darah, menurunkan kekentalan darah, menurunkan keteganggan otot, meningkatkan metabolisme jaringan dan meningkatkan permeabilisme kapiler, Respon dari hangat inilah yang di pergunakan untuk keperluan terapi pada berbagai kondisi dan keadaan dalam tubuh.

Jahe mengandung minyak atsiri zingiberena (zingirona), zingiberol, bisabolena, kurkumen, gingerol, filandrena, dan resin pahit (Irena, 2017). Manfaat jahe adalah menghangatkan tubuh, melancarkan peredaran darah, mengatasi perut kembung, mengatasi demam dan batuk, menghilangkan sakit kepala, mengobati sakit gigi, mengatasi nyeri menstruasi, menurunkan kolestrol, hingga memerangi sel kanker (Pramudyo, 2018). Sensasi pedas, aroma khas dan rasa hangat pada jahe dijumpai dalam minyak atsiri. Rasa hangat pada jahe dapat memperlebar pembuluh darah (vasodilatasi) sehingga darah mengalir lebih cepat dan lancar dan meringankan kerja jantung dalam memompa darah (Susilowati, 2016).

2. Manfaat rendam kaki air hangat jahe dalam menurunkan tekanan darah

Kategori kedua tentang manfaat rendam kaki air hangat jahe dalam menurunkan tekanan darah. Sebagian besar partisipan mengatakan bahwa dengan merendam kaki dengan air hangat jahe dapat menurunkan tekanan darah dan mengurangi nyeri.

Hasil penelitian ini partisipan mengungkapkan bahwa manfaat rendam kaki air hangat jahe dapat menurunkan tekanan darah dan mengurangi nyeri dikarenakan ketika partisipan melakukan rendam kaki air hangat jahe maka akan melancarkan peredaran darah, meningkatkan relaksasi otot, menghilangkan stres, serta memberikan kehangatan pada 
tubuh partisipan sehingga membuat partisipan mengeluarkan keringat.

Prinsip kerja terapi rendam kaki dengan air hangat mempergunakan air hangat yaitu secara konduksi dimana terjadi perpindahan panas/hangat dari air hangat ke dalam tubuh akan menyebabkan pelebaran pembuluh darah dan penurunan ketegangan otot sehingga dapat melancarkan peredaran darah yang akan mempengaruhi tekanan arteri oleh baroreseptor pada sinus kortikus dan arkus aorta yang akan menyampaikan implus yang di bawa serabut membawa isyarat dari semua bagian tubuh untuk menginformasikan kepada otak perihal tekanan darah, volume darah dan kebutuhan khusus semua organ ke pusat saraf simpatis ke medulla sehingga akan merangsang tekanan sistolik yaitu regangan otot ventrikel untuk segera berkontraksi (Santoso dkk, 2015).

Pada awal kontraksi, katup aorta dan katup semilunar belum terbuka. Untuk membuka katup aorta, tekanan di dalam ventrikel harus melebihi tekanan katup aorta. Keadaan dimana kontraksi ventrikel mulai terjadi sehingga dengan adanya pelebaran pembuluh darah, aliran darah akan lancar sehingga akan mudah mendorong darah masuk ke jantung sehingga menurunkan tekanan sistoliknya. Pada tekanan distolik keadaan relaksasi ventrikel isovolemik saat ventrikel berelaksasi, tekanan di dalam ventrikel turun drastis, aliran darah lancar dengan adanya pelebaran pembuluh darah sehingga akan menurunkan tekanan diastolik. Maka dinyatakan ada hubungan yang signifikan antara terapi rendam kaki air hangat dengan penurunan tekanan darah sistolik dan diastolik (Santoso dkk, 2015)

Terapi air hangat bertujuan untuk meningkatkan sirkulasi darah, mengurangi edema, meningkatkan relaksasi otot, menyehatkan jantung, mengendorkan otot-otot, menghilangkan stres, meringankan kekakuan otot, nyeri otot, meringankan rasa sakit, meningkatkan permeabilitas kapiler, memberikan kehangatan pada tubuh sehingga sangat bermanfaat untuk terapi penurunan tekanan darah pada hipertensi (Prananda dkk, 2017).

Pada penelitian Elisabet (2017), rendam kaki dengan menggunakan air hangat dapat merangsang saraf yang berada pada kaki untuk merangsang baroreseptor, baroreseptor merupakan refleks utama dalam pengontrolan regulasi pada denyut jantung dan tekanan darah. Baroreseptor juga menerima rangsangan dari tekanan yang berlokasi di arkus aorta dan pada sinus karotikus. Dengan adanya dilatasi arterior, maka dapat menurunkan tahanan perifer dan dilatasi vena yang menyebabkan darah menumpuk pada vena sehingga mengurangi aliran balik vena, dan menurunkan curah jantung sehingga menurunkan denyut jantung dan daya kontraktilitas pada jantung dan mengakibatkan terjadinya penurunan tekananan darah.

Berdasarkan penelitian Hartati dkk (2016), tentang "Efektivitas pemberian terapi rendam kaki air jahe hangat terhadap penurunan tekanan darah pada lansia dengan hipertensi dipanti werdha pucang gading semarang" bahwa terdapat efektivitas terapi rendam kaki air jahe hangat terhadap penurunan tekanan darah pada lansia dengan hipertensi dan menurut Sucipto \& Setiyono (2018), tentang "Efektivitas terapi rendam kaki dengan air jahe hangat terhadap penurunan tekanan darah pada pasien hipertensi di Puskesmas Kecamatan Cempaka Putih Jakarta Pusat" bahwa terdapat efektivitas terapi rendam kaki dengan air jahe hangat dengan penurunan tekanan darah sistolik dan diastolik.

Hasil penelitian lain yang sejalan dengan penelitian ini yaitu yang dilakukan Nurahmandani, (2017). Yaitu adalah Tekanan darah sesudah diberikan rendam kaki air jahe hangat pada lansia dengan hipertensi di Panti Werdha Pucang Gading Semarang ratarata tekanan darah sistolik dan distolik 
sebesar 140.12/84.88 $\mathrm{mmHg}$, dengan standar deviasi 5.476/3.199 $\mathrm{mmHg}$, nilai tengah $140.00 / 85.00 \mathrm{mmHg}$ tekanan darah sistolik terendah 133/81 $\mathrm{mmHg}$ dan tekanan darah sistolik tertinggi 153/91 mmHg. Hasil penelitian menunjukkan bahwa terjadi penurunan tekanan darah sistolik dan diastolik sebelum maupun setelah diberikan rendam kaki air jahe hangat.

3. Waktu melakukan rendam kaki air hangat jahe

Kategori ketiga tentang waktu melakukan rendam kaki air hangat jahe. Sebagian besar partisipan mengatakan bahwa partisipan melakukan rendam kaki air hangat jahe pada pagi hari dan waktu yang dilakukan sekitar 10-20 menit.

Hasil penelitian ini partisipan mengungkapkan bahwa waktu yang dilakukan pada pagi hari dikarenakan pagi hari suasana dingin dan pagi hari pembuluh darah belum lancar setelah melakukan rendam kaki air hangat jahe membuat pembuluh darah menjadi lancar dengan lama waktu perendaman sekitar 10-20 menit sampai airnya sudah tidak terlalu hangat lagi.

Merendam kaki di baskom berisi dengan air hangat dapat di lakukan dengan suhu $42^{\circ} \mathrm{C}$ selama $15-30$ menit dengan ketinggian air semata kaki (Kwang, 2014). Merendam kaki dibaskom dengan suhu antara $40^{\circ} \mathrm{C}$ selama 15-30 menit sehingga betis bisa terendam sebagian (Dadan, 2014).

4. Prosedur dalam melakukan rendam kaki air hangat jahe

Kategori keempat tentang prosedur dalam melakukan rendam kaki air hangat jahe. Sebagian besar partisipan mengatakan prosedur yang dilakukan yaitu jahe diirisiris/ditumbuk/digeprek, direbus, masukkan ke wadah, kaki direndam sebatas mata kaki.

Hasil penelitian ini partisipan mengungkapkan bahwa prosedur dalam melakukan rendam kaki air hangat jahe dengan jahe diirisiris/ditumbuk/digeprek untuk lebih cepat mengeluarkan zat yang terkandung didalam jahe tersebut dan sesuai kemauan partisipan dalam mengolah jahe yang digunakan, air yang disediakan dimasukkan kewadah bersamaan dengan jahe yang telah diolah partisipan dan kaki direndam sebatas mata kaki untuk mengambil alih fungsi herbal untuk memanaskan seluruh tubuh dengan mengunakan air hangat jahe yang telah diolah partisipan.

Metode yang umum digunakan dalam hidroterapi yaitu dengan merendam kaki di air hangat, dalam metode ini kaki direndam hingga sebatas pergelangan kaki. air hangat dapat membantu meningkatkan sirkulasi darah dan vasodilatasi (perlebar pembuluh darah) (Adhi, 2019).

Merendam kaki di baskom berisi dengan air hangat dapat di lakukan dengan suhu $42^{\circ} \mathrm{C}$ selama $15-30$ menit dengan ketinggian air semata kaki (Kwang, 2014). Ada banyak titik akupuntur di telapak kaki dan 6 meridian (hati, empedu, kandung kemih, ginjal, limpa dan perut) ada dikaki. Merendam kaki dalam air panas dapat mengambil alih fungsi herbal untuk memanaskan seluruh tubuh, meningkatkan sirkulasi darah ke bagian atas tubuh dan juga melepaskan tekanan (Dadan, 2014).

5. Jenis jahe yang digunakan

Kategori kelima tentang jenis jahe yang digunakan. Sebagian besar partisipan mengungkapkan bahwa paling banyak digunakan jahe putih dan jahe kuning.

Hasil penelitian ini partisipan mengungkapkan bahwa jenis jahe yang sering digunakan yaitu jahe putih dan jahe kuning dikarenakan jahe tersebut sering digunakan untuk memasak dirumah dan mudah didapatkan.

Terdapat tiga jenis jahe yang dibagi berdasarkan ukuran, bentuk, dan warna akar rimpangnya. Ketiga jenis jahe tersebut yaitu jahe kuning, jahe putih dan jahe merah (Adiguna,2014). 
Jahe putih memiliki akar rimpang yang beruas kecil, dan hanya sedikit menggembung. Minyak atsiri yang terdapat pada jahe putih lebih banyak dibandingkan dengan jahe kuning, sehingga lebih tajam dan pedas (Adiguna, 2014). Kandungan minyak atsiri pada jahe putih 1,5-3,5\% (Pramudyo, 2018).

Jahe kuning mempunyai ciri rimpang yang berwarna kuning emas. Berukuran lebih besar dan gemuk, terlihat menggembung dibandingkan dengan jahe putih dan jahe merah (Adiguna, 2014). Kandungan minyak atsiri pada jahe kuning 0,82-1,66\% (Pramudyo, 2018).

Jahe merah memiliki akar rimpang berwarna merah. Ukurannya lebih kecil dibandingkan dengan jahe kuning dan jahe putih. Jahe merah juga memiliki kandungan minyak atsiri dalam jumlah banyak sehingga banyak dimanfaatkan sebagai ramuan obat herbal (Adiguna, 2014). Kandungan minyak atsiri jahe merah 2,58-3,90\% (Pramudyo, 2018).

Jahe mengandung minyak atsiri zingiberena (zingirona), zingiberol, bisabolena, kurkumen, gingerol, filandrena, dan resin pahit (Irena, 2017).

Sensasi pedas, aroma khas dan rasa hangat pada jahe dijumpai dalam minyak atsiri. Rasa hangat pada jahe dapat memperlebar pembuluh darah (vasodilatasi) sehingga darah mengalir lebih cepat dan lancar dan meringankan kerja jantung dalam memompa darah (Susilowati, 2016).

Berdasarkan penelitian Hartati dkk (2016) dan Sucipto \& Setiyono (2018) di dapatkan hasil adanya hubungan rendam kaki air jahe hangat terhadap penurunan tekanan darah pada penderita hipertensi

6. Efek samping yang muncul setelah melakukan rendam kaki air hangat jahe

Kategori keenam tentang efek samping yang muncul setelah melakukan rendam kaki air hangat jahe. Sebagian besar partisipan mengungkapkan bahwa tidak ada efek samping yang muncul setelah melakukan rendam kaki air hangat jahe.

Hasil penelitian ini partisipan mengungkapkan bahwa tidak ada efek samping yang muncul setelah melakukan rendam kaki air hangat jahe. Terapi ini menggunakan pengobatan dari luar yaitu peredaman kaki dan kemungkinan efek yang timbul sangat kecil ditemukan. Dalam penelitian ini peneliti belum menemukan literatur tentang efek samping pada terapi rendam kaki air hangat jahe.

\section{Kesimpulan}

Berdasarkan hasil penelitian dan pembahasan mengenai pengalaman rendam kaki air hangat jahe dalam menurunkan tekanan darah pada pasien hipertensi di wilayah Puskesmas Tanjung Hulu Pontianak Timur, dapat ditarik kesimpulan sebagai berikut:

Ada enam tema terdiri dari, perasaan setelah melakukan rendam kaki air hangat jahe, manfaat rendam kaki air hangat jahe dalam menurunkan tekanan darah, waktu melakukan rendam kaki air hangat jahe, prosedur dalam melakukan rendam kaki air hangat jahe, jenis jahe yang digunakan, efek samping yang muncul setelah melakukan rendam kaki air hangat jahe.

Berdasarkan hasil penelitian ini, maka penulis menyarankan kepada bagi masyarakat diharapkan penderita hipertensi dapat memanfaatkan terapi rendam kaki air hangat jahe sebagai terapi alternatif dalam menurunkan tekanan darah pada penderita hipertensi dan dapat melakukan terapi air hangat jahe secara rutin dan disiplin, terapi rendam kaki air hangat jahe dapat dilakukan di rumah agar lebih mudah untuk mempersiapkan alat-alatnya. Bagi profesi keperawatan penelitian ini diharapakan mampu menjadi alternatif yang lain dalam memberikan masukan kepada penderita hipertensi tentang pemilihan terapi rendam kaki air hangat jahe sebagai alternatif dalam menurunkan tekanan darah, dan juga mampu menambahkan pengetahuan perawat dalam bidang komplementer. Bagi peneliti selanjutnya sebaiknya penelitian selanjutnya bisa membahas pengalaman 
efek samping yang khusus dalam terapi rendam kaki air hangat jahe dikarenakan didalam penelitian ini peneliti belum menemukan efek samping yang dirasakan oleh partisipan pada saat penelitian.

\section{UCAPAN TERIMA KASIH}

Penelitian ini dapat terlaksana berkat dukungan dan Kerjasama dari berbagai pihak, oleh karena itu kami selaku peneliti mengucapkan terima kasih yang tak terhingga kepada :

1. Ibu Fajar Yousriatin, M. Kes selaku Ketua STIKes Yarsi Pontianak yang telah memberikan dukungan dan fasilitas selama proses penelitian.

2. Kepala Lembaga Penelitian dan Pengabdian Masyarakat ibu Ns. Diena Juliana, S. Kep., M. Kes yang telah banyak membanti dan mengarahkan serta memfasilitasi untuk publikasi hasil penelitian ini.

3. Serta seluruh responden yang sudah bersedia terlibat dalam proses penelitian ini.

\section{Referensi}

Adhi \& Nurin. (2019). Keajaiban Air Mineral Bagi Kesehatan. Yogyakarta: Unicorn publishing.

Adiguna Parjan. (2014). The Secret Of Herbal. Yogyakarta: Cemerlang Publishing.

Creswell. John W. (2013). Research Design Qualitative, Quantitative, And Mixed Methods Approaches. Third Edition. Terjemah. Achmad Fawaid. Research Design Pendekatan Kualitatif, Kuantitatif, Dan Mixel. Yogyakarta: Pustaka Pelajar.

Dadan. (2014). Teknik Mudah \& Lengkap Pijat Refleksi Cepat Sembuh Dari Aneka Penyakit Kronis, Tanpa Operasi, Tanpa Suntik, Tanpa Biaya Mahal. Yogyakarta: MEDIA PRESSINDO.

Dharma Kelana Kusuma. (2017). Metodologi Penelitian
Keperawatan. Jakarta: Buku Kesehatan.

Dinas Kesehatan Kota Pontianak. (2019). Penyakit Hipertensi Di Tahun 2019.

Elisabet \& Evelin. (2017). Perubahan Tekanan Darah Sebagai Respon Terhadap Hidroterapi Rendam Kaki Dengan Air Hangat Pada Wanita Dewasa Hipertensi Tahap I. Jurnal Skolastik Keperawatan. Vol. 3. Diakses Pada 04 Februari (2020) dari http://jurnal.unai.edu/index.php/js k/article/download/579/449/

Elvi Oktarina Dkk. (2018). Studi Fenomenologi Tentang Pengalaman Pasien Hipertensi Terhadap Perawatan Dirinya. Diakses pada 19 Juni (2020) dari http://ners.fkep.unand.ac.id/index.p $\mathrm{hp} /$ ners/article/download/176/138

Hartati (2016). Efektivitas Pemberian Terapi Rendam Kaki Air Jahe Hangat Terhadap Penurunan Tekanan Darah Pada Lansia Dengan Hipertensi. Diakses pada 03 Maret (2020) dari http://ejournal.stikestelogorejo.ac. id/index.php/ilmukeperawatan/arti cle/download/500/449

Hastanto. (2019). Farmakologi 3. Jilid 3. Yogyakarta: Deepublish.

Hidayat Aziz Alimul. (2017). Metodologi Penelitian Keperawatan Dan Kesehatan. Jakarta: Salemba Medika.

Huether \& McCance. (2019). Buku Ajar Farmakologi. VOL 2. Singapore: ELSEVIER.

Irena Manganti. (2017). Ramuan Herbal Untuk Mempercepat Kehamilan. Yogyakarta: Araska.

Kementrian Kesehatan Republik Indonesia. (2018). Hasil Riset Kesehatan Dasar. Jakarta: Kementrian Kesehatan Republik Indonesia.

Kurniadi Helmanu \& Nurrahmani Ulfa. (2015). Stop Diabetes Hipertensi Kolestrol Tinggi Jantung Koroner. Yogyakarta: Istana Media 
Kusuma \& Artistiana. (2013). Bebas Hipertensi Dengan Self Hypnosis. Jakarta: NouraBooks.

Kwang Jae Sun. (2014). Jus Detoks Bebas Penyakit Dalam 3 Minggu. Jakarta Selatan: Noura Books.

Lemone Dkk.(2017). Buku Ajar Keperawatan Medikal Bedah Gangguan Kardiovarkuler. Jakarta: EGC.

Marliana. (2017). Analisis Asuhan Keperawatan Pada Pasien Hipertensi Dengan Masalah Nyeri Di Instalasi Gawat Darurat Rsud Prof Dr. Margono Soekarjo Purwokerto. Gombong.

Moleong. L. (2014). Metodologi Penelitian Kualitatif. Edisi Revisi. Bandung: PT Remaja Rosdakarya.

Muttaqin Arif. (2012). Asuhan Keperawatan Klien Dengan Gangguan Sistem Kardiovaskuler. Jakarta: Salemba Medika.

Nurarif Amin Huda \& Kusuma Hardhi. (2016). Asuhan Keperawatan Praktis. Jilid 1. Jogyakarta: Medi Action.

Ode La Sarif. (2012). Asuhan Keperawatan Gerontik. Yogyakarta: Nuha Medika.

Polit. D. F \& Beck. C. T. (2012). Nursing Research: Generating And Assessing Evidence For Nursing Practice. Ninth Edition. Philadelphia: Lippincott Williams \& Wilkins.

Pramudyo Adi. (2018). Budi Daya Dan Bisnis Jahe, Lengkuas, Kunyit Dan Kencur. Jakarta: AgroMedia Pustaka.

Prananda Yahya. (2017). Pengaruh Pemberian Rendam Kaki Air Hangat Terhadap Penurunan Tekanan Darah Pada Lansia Dengan Hipertensi. Diakses Pada 04 Februari (2020) dari http://jurnal.untan.ac.id/index.php /jmkeperawatanFK/article/downlo $\mathrm{ad} / 22001 / 17638$

Prasetyaningrum Yunita Indah. (2014). Hipertensi Bukan Untuk Ditakuti. Jakarta: FMedia.
Prasetyo \& Setiawan. (2015). Metodologi Penelitian Kesehatan Untuk Mahasiswa Kesehatan. Yogyakarta: GRAHA ILMU.

Putri \& Amalia. (2019). Terapi Komplementer Konsep Dan Aplikasi Dalam Keperawatan. Yogyakarta: PT. PUSTAKA BARU.

Rottie. V Julia Dkk. (2017). Pengaruh Terapi Rendam Kaki Dengan Air Hangat Terhadap Penurunan Tekanan Darah Pada Pasien Dengan Hipertensi. Ejournal Keperawatan (e-Kp). Vol. 5. Diakses Pada 04 Februari (2020) dari

https://media.neliti.com/media/pu blications/105810-ID-pengaruhterapi-rendam-kaki-dengan-airh.pdf

Santoso Dwi Agung. (2015). Pengaruh Terapi Rendam Kaki Air Hangat Terhadap Penurunan Tekanan Darah Pada Lansia Penderita Hipertensi. Diakses Pada 03 Februari (2020) dari http://jurnal.untan.ac.id/index.php /jmkeperawatanFK/article/downlo ad/11393/10796

Satria Wikanda Putra. (2014). Sehat Dengan Terapi Refleksi Dan Herbal. Yogyakarta: Ar. Ruzz Media.

Semiawan. (2010). Metode Penelitian Kualitatif. Cikarang: Grasindo.

Smeltzer C Suzanne et al. (2010). Brunner \& Suddarth's Textbook Of Medical Surgical Nursing 12th ed. China: Aptara,Inc.

Soeryoko H. (2010). Tanaman Obat Terpopuler Penurun Hipertensi. Yogyakarta: ANDI.

Streubert. H. J \& Carpenter. D. R. (2011). Qualitative Research in Nursing Advancing the Humanistic Imperative. Fifth Edition. Philadelphia: Lippincott Williams \& Wilkins.

Sucipto Muhamad Bayu \& Sutiyono Erwan. (2018). Efektivitas Terapi Rendam Kaki Dengan Air Jahe Hangat 
Terhadap Penurunan Tekanan Darah Pada Pasien Hipertensi. Diakses Pada 03 Februari (2020) dari

http://perpus.fikumj.ac.id/index.p $\mathrm{hp}$ ? $\mathrm{p}=$ fstreampdf \&fid $=12388 \&$ bid $=4761$

Sugiyono. (2013). Metodelogi Penelitian Kuantitatif, Kualitatif Dan $R \& D$. Bandung: ALFABETA.

Susilowati. (2016). 50 Herbal Dan Suplemen Yang Memperpanjang Usia. Yogyakarta: Kyta.
Sutanto. (2010). Penyakit Modern. Ed 1. Yogyakarta: ANDI.

Wahyuningsih. (2013). Penatalaksanaan Diet Pada Pasien. Yogyakarta: Graha Ilmu.

WHO (World Health Organization). (2015). Hypertension. Diakses Pada 01 Februari (2020) dari https://www.who.int/healthtopich/hypertension

Yasmara Dkk. (2017). Rencana Asuhan Keperawatan Medikal Bedah. Jakarta: EGC. 